\title{
Rевенст автісі: Nodulation and yield of greengram (Vigna radiata L.) influenced by integrated weed management practices
}

\author{
T. MUTHURAM, R. KRISHNAN, S. GANESH AND G. S. KANNAN
}

Article Chronicle: Received :

14.07.2017;

Accepted :

29.07.2017

\section{KeY WoRds:}

Greengram, PE-

Pendimethalin, EPOE-

Quizalofop-ethyl and imazethapyr, Rotary weeding, Hand weeding, Root nodule

SUMMARY : A field experiment was conducted during the Rabi season (November-January) 20132014 to determine the most effective integrated methods of weed control. The experiment was laid out in Randomized Block Design with three replications and the test variety of the crop was Co 6 greengram. The treatments involving pre-emergence herbicides pendimethalin followed by eitherhand weeding, rotary weeding or early post-emergence herbicides viz., imazethapyr, quizalofop-ethyl. In addition, early post-emergence herbicides application followed by mechanical weeding, hand weeding or rotary weeding twice and weed free condition were also tested with unweeded check. Most effective method of weed control and produced the maximum seed yield by weedy condition for the entire crop season reduced the seed yield by $30 \%$ as compared to chemical weeding. Integration of PE herbicide with EPOE herbicide provided better growth, yield attributes and consequently higher yield. In respect of nodulation $\mathrm{T}_{8} \mathrm{PE}$ herbicide with EPOE herbicide treatment recorded the highest nodule number of 29.00 plant $^{-1}$ at 30 DAS.

How to cite this article : Muthuram, T., Krishnan, R., Ganesh, S. and Kannan, G. S. (2017). Nodulation and yield of greengram (Vigna radiata L.) influenced by integrated weed management practices. Agric. Update, 12 (TECHSEAR-4): 1130-1134; DOI: 10.15740/HAS/AU/12.TECHSEAR (4)2017/1130-1134.

Author for correspondence :

\section{T. MUTHURAM}

Department of

Agronomy, Faculty of

Agriculture and Animal

Husbandry, Gandhigram

Rural Institute,

DINDIGUL (T.N.) INDIA

Email: agrimuthuram@

gmail.com

See end of the article for

authors' affiliations 